\title{
Modeling and Management of Existing Watershed by using QGIS
}

\author{
${ }^{1}$ Mrs. Supriya Patil, ${ }^{2}$ Mr. Gaurav Borate, ${ }^{3} \mathrm{Mr}$. Saurabh Sathe, ${ }^{4} \mathrm{Mr}$. Avinash Late, ${ }^{5} \mathrm{Mr}$. Arbaj Shaikh \\ ${ }^{1}$ Assistant Professor, ${ }^{2,3,4,5}$ Students, D.Y. Patil College of Engineering, Akurdi, Pune, India \\ 11 supriyap866@ gmail.com, ${ }^{2}$ gdborate100@gmail.com, ${ }^{3}$ saurabhsathe1924@ gmail.com, \\ 4avinashlate04@yahoo.com, ${ }^{5}$ arbajshaikh7377@gmail.com
}

\begin{abstract}
In this project we have made an effort to be acquainted with the aspect of 'Watershed Management and Development' using Geographical Information System. As there's continuous increase in population and continuous degradation of environment. Also India is facing scarcity of water. Therefore watershed development is most suitable choice for development of rural areas. The main aim of this project is that the all of these engineering knowledge like GIS we've learned and apply it to different rural areas and lift economy as well as to improve the lifestyle of village people. GIS is computer based information management system which collects and stores specially reference multivariate (involving number of attributes or parameters) and multidate data. The name implies that the system deals with geographical space on the earth and its features. We have prepared the various layers like Gambian bund, cement nala bund, loose boulder structures, and percolation. We fix the position of those watershed harvesting structures according to their suitability. Also we show different contributory areas and we calculate runoff from each of the outlet. The above mention work is carried out in QGIS 2.18
\end{abstract}

Keywords — Watershed Management, Digital Elevation Model, Geographic Information System, Watershed delineation, Sustainable Development, Rational Formula

\section{INTRODUCTION}

Our environment is getting progressively degraded because of over exploitation of natural resources, population pressure, indiscriminate tree falling, over grazing, unsound agricultural practices etc. All these factors are contributing towards degradation. In the degraded landscape there's little or no tree cover subsequently little soil cover. The rain water isn't able to percolate within the ground and flows away to the stream. Together with this water we lose rich top soil which is crucial for any vegetation to grow.

Primary objective of program is to conserve natural resources. Top 6 inches of soil are more fertile, most of the soil nutrients are present in this 6 inches' layer. Top soil eroded per annum with flowing water so we have to forestall that. Similarly rain water also which flow away which has to be stop. If speed of flowing water is reduced so it does not wash away top soil. So our basic involves soil and water conservation. For example, it like a bank only if we have money in the bank then only you can withdraw it. Similarly bank of watershed is hills. If there are enough trees, grasses and different conservation treatments then hills can conserve water within them. If there is enough shed, then there is less evaporation. The rain water will not fall directly on the soil but rather it impacts will be cushion by vegetative cover. Otherwise it will carry away loose top soil with it by force.
So just we don't have to stop water but we also have to cover it, i.e. protect it from direct sunlight, animals and rainfall.

So watershed development program is extremely beneficial for the development of the families of the village well as country. The population of cities is rising because of unemployment in rural areas so watershed development is just one option for the development rural areas.

\section{STUdy AREA}

Ralegan Siddhi is a village situated in Parner taluka, Ahmednagar District of Maharashtra state in India. Ralegan Siddhi is situated $87 \mathrm{~km}$ far from Pune city. The study area of Ralegan Siddhi village for watershed lies between geographic latitudes $18.9156^{\circ} \mathrm{N}$ and $74.4145^{\circ} \mathrm{E}$. The temperature is between $12^{\circ} \mathrm{C}$ to $44^{\circ} \mathrm{C}$. The average rainfall lies between 450 to $650 \mathrm{~mm}$. The areas of village comes under the rain shadow zone. The village has carried out many programmes like terracing to decrease soil erosion and creating canals to retain rainwater, tree planting. This village uses wind mills, solar power, biogas etc. as energy resources. The area of village is 982.31 hectare, but the part of 300 hectare is not available for cultivation. In 1975, the village was affected by drought, poverty prevailed.

The village tank was not holding the water, due to leakage in embankment wall. Afterwards work began with the 
construction of percolation tank. The Social worker Anna Hazare motivated villagers to contribute their labour for repairing the embankment. Now the village has adequate water throughout the year as well as milk bank, school and grain bank, without having any long time poverty.

\section{METHODOLOGY}

\section{Site Selection:}

Ralegan Siddhi is a village in ParnerTaluka, Ahmednagar District, Maharashtra state. The study lies between geographic latitudes $18.9156^{\circ} \mathrm{N}$ and $74.4145^{\circ} \mathrm{E}$. Ralegan Siddhi is $87 \mathrm{~km}$ away from Pune. The area comes under the rain shadow zone. The rainfall ranging between 450 to $650 \mathrm{~mm}$. and temperature ranging between 12 to $44^{\circ}$.

\section{Pre Work:}

In pre work we collected and studied previous literature data about Watershed management and development programs.

\section{Field Investigation:}

a) Survey of Watershed:

In preliminary survey we studied about the selected region considering on various parameters.

b) Data collection from study area:-

- Type of water harvesting structures

- Methods of construction

- Position of structure

- Purpose of structure

- Overall cost on construction of structure

- Efficient management of water

- Social impact on society

\section{Watershed Modeling:-}

a) Digital Elevation Model (DEM):

It is $3 \mathrm{D}$ representation of surface nature. DEM contain elevation of terrain over a specific area. The actual location associated with elevation data is calculated by software reading of actual DEM file, knowing the precise location of data value inside the DEM file. DEM of area can be obtained from the BHUVAN website.

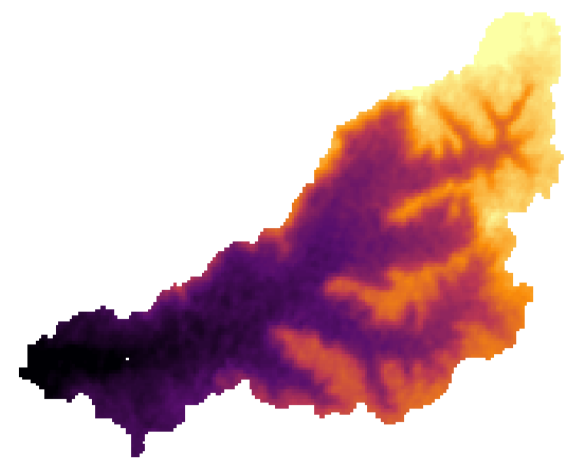

Fig -1: DEM of Ralegan Siddhi b) Raster file generation:

Raster data is composed of grids of small cells. Value is assigned to each of the cell. This value represents the nature of data present at corresponding location. The main use of raster data is that it store map information in digital format. For the watershed delineation we use GRASS plug-in. After constructing a new map set in GRASS and selecting the region, next we have to create raster files such drainage direction, water accumulation, drainage network and sub basins.

Topography of terrain is represented by digital elevation data. This data set consists of elevation in the form of grid points in raster file. Flow accumulation maps shows area where water is accumulated.

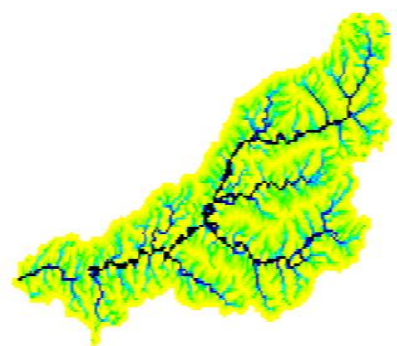

Fig -2: Water Accumulation

Drainage network maps are useful to trace the stream lines. Also these are useful to decide the locations of structures.

Water harvesting structures are located on the stream lines.

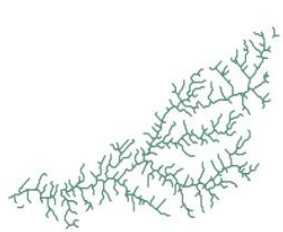

Fig -3: Drainage Network

Drainage basin is a natural unit draining runoff water to a common point. The water flowing through a number the gullies and joins to common stream.

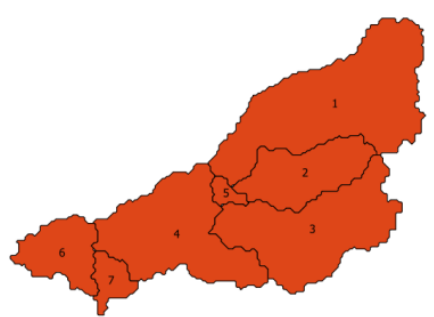

Fig -4: Sub Basins
Drainage direction determines the direction of flow. Flow direction is assign to the every cell in the raster. 


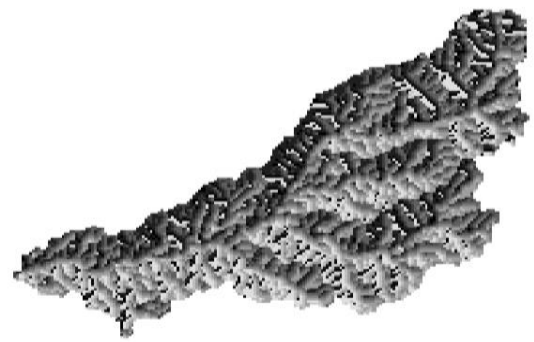

Fig -5: Drainage Direction

c) Extraction of contour:

Contours are the lines joining the points of equal elevation. So for the analysis point of view contours are much more essential. From the DEM we can easily extract the contour of our study area. Contours are the vector files.

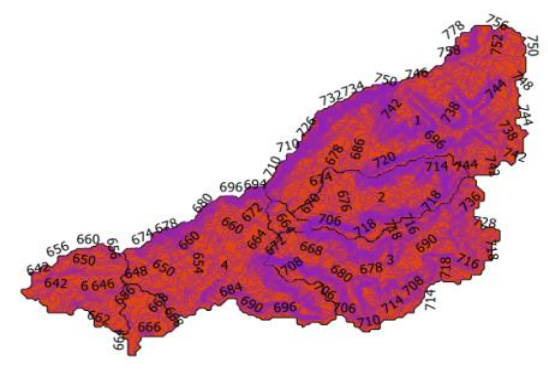

Fig -6: Contour

d) Land Use and Land Cover (LULC) maps:

LULC maps shows information about the current landscape of the area. LULC maps plays crucial role in watershed management, planning and monitoring. For discharge calculation we have to consider the landscape of that area.

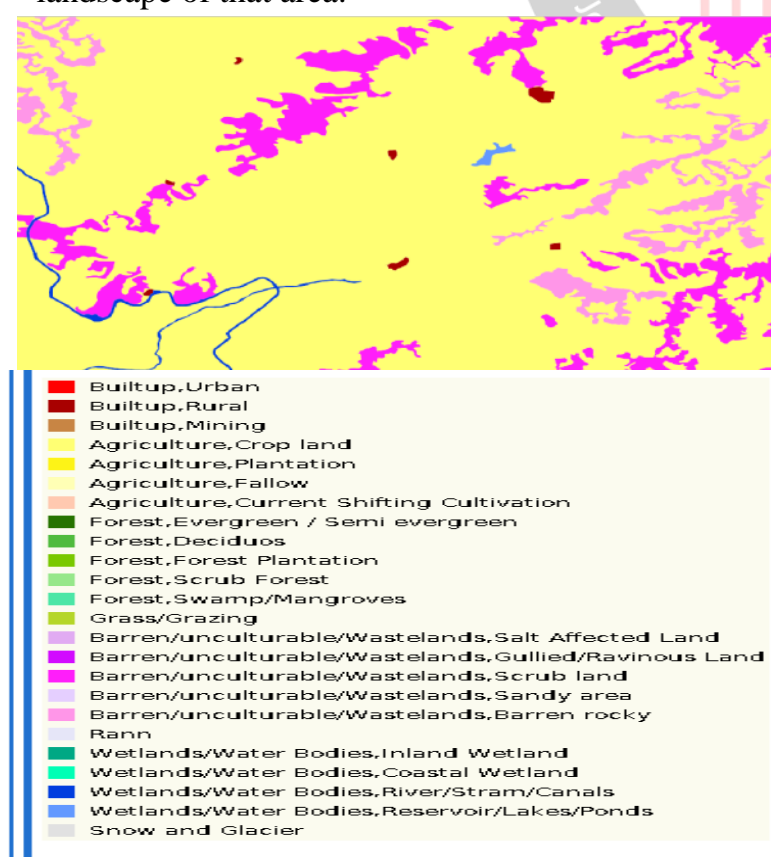

Fig -7: Land Use Land Cover Map

e) Vector file generation:

After digitizing, the various layers are constructed such as gabion bund, check dam, loose boulder structure and
Percolation tank. According to nature of ground slope, discharge and purpose of the structure we finalize the location of these structures.

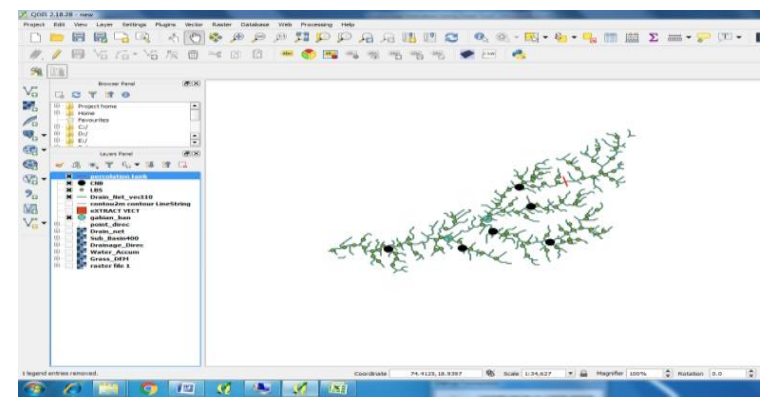

Fig -8: Showing location of water harvesting structures

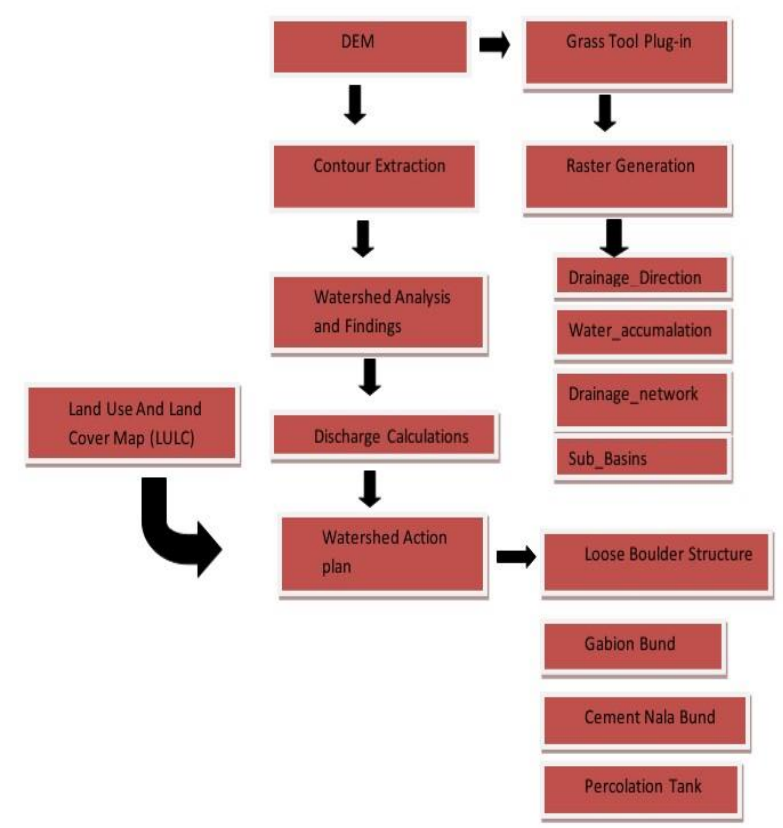

Chart 1: Flow chart of Watershed Delineation

\section{RESULTS}

Discharge Calculations:-

Rational formula-

$$
Q=0.0028 C I A
$$

C- Runoff coefficient

I - Intensity of rainfall $(\mathrm{mm} / \mathrm{hr})$

Assume rainfall intensity as $22 \mathrm{~mm} / \mathrm{hr}$. (Neglecting infiltration and evaporation losses)

A- Area of watershed (hect)

Table-1: Runoff Calculations

\begin{tabular}{|c|c|c|c|c|}
\hline cat & $\begin{array}{c}\text { Area } \\
\text { (Hect) }\end{array}$ & intensity(mm/hr) & $\begin{array}{c}\text { Runoff } \\
\text { Coefficient }\end{array}$ & $\begin{array}{c}\text { Discharge } \\
\text { (m3/sec) }\end{array}$ \\
\hline 1 & 347.532 & 22 & 0.5 & 10.703 \\
\hline 2 & 125.459 & 22 & 0.5 & 3.864 \\
\hline 3 & 245.162 & 22 & 0.5 & 7.550 \\
\hline 4 & 231.553 & 22 & 0.5 & 7.131 \\
\hline 5 & 12.948 & 22 & 0.5 & 0.398 \\
\hline 6 & 86.164 & 22 & 0.5 & 2.653 \\
\hline 7 & 33.012 & 22 & 0.5 & 1.016 \\
\hline
\end{tabular}


Table -2: Estimated no of structures

\begin{tabular}{|l|l|}
\hline Structures & Nos. \\
\hline Percolation tank & 1 \\
\hline Gabian Bund & 2 \\
\hline Cement Nala Bund & 6 \\
\hline Loose Boulder Structures & 91 \\
\hline
\end{tabular}

\section{Capacity of Percolation Tank:-}

$$
\mathrm{V}=0.5 * \mathrm{H}^{*}(\mathrm{~A} 1+\mathrm{A} 2)
$$

Upper contour $=704 \mathrm{~m}$

Inner contour $=698 \mathrm{~m}$

Where,

$\mathrm{V}=$ volume of $\operatorname{tank}\left(\mathrm{m}^{3}\right)$

$\mathrm{H}=$ height of tank $=6 \mathrm{~m}$

$\mathrm{A} 1=$ Area of outer contour $\left(\mathrm{m}^{2}\right)=85,463 \mathrm{~m}^{2}$

A2 $=$ Area of inner contour $\left(\mathrm{m}^{2}\right)=27,849 \mathrm{~m}^{2}$

$\mathrm{V}=0.5 * 6 * 85463 * 27849=3,39,936 \mathrm{~m}^{3}$

\section{CONCLUSION}

Watershed development program is very vital for the development of the village as well as country. The rain water that we receive is gets flown away easily. Also it washes fertile soil. To stop that gabian bund, cement nala bund, loose boulder structures, and percolation are plays important role. Storing of water below the ground is more beneficial than storing it on surface. Total discharge that we have calculated is $33.31 \mathrm{~m} 3 / \mathrm{sec}$. Capacity of percolation tank is about $3,39,936 \mathrm{~m}^{3}$.

Finalizing the location of water structure is easy and economical by using GIS tool. Fundamentals of watershed and amalgamation with GIS technique can be successfully implemented in development of new watershed. Future scope includes applying same methodology to new area. So in this project it is shown that geo informatics and its applications can be successfully used in civil engineering.

\section{ACKNOWLEDGEMENT}

The authors wish to acknowledge the constant support from the DYPCOE administration and civil engineering staff, especially our project guide Mrs. Supriya Patil.

This project couldn't possible without the valuable support by grampanchayat of Ralegan Sidhhi.

\section{REFERENCES}

[1] Mr. Chetan Bansode, Mr. Vishal Bhosale, Mr. Akash Dongare, Mr lalitShirsagar, Mr Aniket Malwadkar, Prof. P.D. Sabale'Watershed Development by Using GIS and Remote Sensing For Water Budgeting'

[2] Dr. Kanak Moharir, Dr. Chaitanya Pande" Planning of conservation measures for watershed management and development by using Geospatial Technology - A Case study of Patur watershed in Akola district of Maharashtra"

[3] Mr. P. Balamurugan, Mr. Boobathiraja, Mr. T. Guhan, Mr. B. Janarthanan“ Study of ground water pollution around an industry using GIS"

[4] Mr. Rajeev, Mr. Sultan Singh “ Watershed Management- A GIS Approach

[5] T. Subramani, S. Krishnan, P.K. Kumar ' Study of ground water quality and GIS application for Coonor taluka in Nilgiri District'

[6] Bangar Sunil. R , Patil Pramod. Z, Kashid Vinod. H "Watershed Management by Using QGIS Software"

[7] Raghunath Pal, Padminipani "Remote Sensing And Gis-Based Analysis Of Evolving Planform

Morphology Of The Middle-Lower Part Of The Ganga River, India"

[8] Suhas P Wani And Kaushal K Garg "Watershed Management Concept And Principles"

[9] Mr. Rajwardhan Patil ,Sanket Huljute ,Ranjit Patil, Ashish Barge , Monil Mahajan "Watershed Management Of Drought Prone Area Using G.I.S."

[10] P. D. Sreedevi, S. Owais, H. H. Khan And S. Ahmed "Morphometric Analysis Of A Watershed Of South India Sing Srtm Data And Gis"

[11] Thorat Mm “Watershed Management"

[12] Book- Mrudugandh, Ramchandra Zagade Publication- Hind Swaraj Trust. 